\title{
Writing the Nation: Re-thinking the Masculinist Project in Eça de Queirós's Ilustre casa de Ramires
}

\author{
KATHRYN BISHOP-SANCHEZ
}

University of Wisconsin-Madison

\begin{abstract}
This article examines José Maria de Eça de Queirós's novel A ilustre casa de Ramires (1900) through a focus on the writing process of the main protagonist, Gonçalo Mendes Ramires, who attempts to produce a historical novella of his ancestry. Drawing on Hélène Cixous's concept of écriture féminine and the visceral experience of writing through the body, I analyze the protagonist's quest for political advancement and social acceptance. If Ramires yearns for enhanced virility in male-dominated political and literary circles, Eça's ironic textual subtleties, humor, and multifaceted narrative all serve to question established norms of gender, power, and sexuality. In the end, both historiography and political glory emerge as ambivalent phenomena.
\end{abstract}

Keywords: Historiography, novel, Portugal, l'écriture féminine, Hélène Cixous

In one of the most brilliant, humorous, and politically charged scenes of Os Maias (1888), João da Ega organizes an ostentatious dinner at the Hotel Central where, in animated conversation, the guests discuss the future of Portugal and the prospects of national bankruptcy, revolution, political and economic reform, a Spanish invasion, and the loss of the colonies. Carried away by his radical ideas, Ega challenges the more conservative position of his dinner companions:

Então ignoravam que esta raça, depois de cinquenta anos de constitucionalismo, criada por esses saguões da Baixa, educada na 
piolhice dos liceus, roída de sífilis, apodrecida no bolor das Secretarias, arejada apenas ao domingo pela poeira do Passeio, perdera o músculo como perderão carácter, e era a mais fraca, a mais cobarde raça da Europa? (210-11)

When another guest, the high-minded Craft, suggests that Ega's accusations only ring true for the people of Lisbon, Ega retorts with what has become one of Eça's most memorable phrases: "Lisboa é Portugal [...]. Fora de Lisboa não há nada. O país está todo entre a Arcada e S. Bento!” (211).

Ega's humorous hyperbole of Lisbon as Portugal, situated between the ministries of the Arcada in the Terreiro do Paço and the São Bento parliamentary palace, stands in stark contrast to the rest of Portugal as a political, social, or cultural vacuum, i.e. the província. This juxtaposition resonates with a passage from Eça's posthumous novel, pointedly titled, A capital (1925). When an acquaintance asks the protagonist, Artur Corvelo, if he lives in Lisbon, the narrator relates Corvelo's heartfelt response: "Infelizmente não" (273); what brought him to Lisbon was "a publicação dum livro de versos, a representação dum drama, o desejo dum meio inteligente, literário, o horror à província" (273). In the província, "estava-se tão atrasado como no tempo dos frades. Uma coleção de pequenos burgueses, imbecis, rotineiros, caquéticos; meia dúzia de ricaços que seduzem as raparigas, e fazem as eleições” (273).

The previous two examples illustrate a frequent concern in Eça de Queirós's novels: the relationship between Lisbon and the província in terms of cultural awareness, politics, education, progress, and human values. Toward the end of his life, Eça returns to this preoccupation with even more emphasis. In the complex semi-posthumous novel A ilustre casa de Ramires (1900), the author positions the protagonist, Gonçalo Mendes Ramires, in rural Portugal, although he strives for political success and recognition in the country's capital. ${ }^{1}$ The result is an elaborate portrayal of provincial fin-de-siècle Portugal. As Eça describes it, in an 1897 letter to Henrique Casanova: "É uma anedota

\footnotetext{
${ }^{1}$ In Queirosian studies, the term semi-posthumous has been used for the novels Eça had almost finished prior to his death, even if the final version had not been entirely revised, and that were published a short time after his death. This designation is mainly used for A ilustre casa de Ramires (1900), A cidade e as serras (1901), and A correspondência de Fradique Mendes (1900). See Reis, O essencial 30.
} 
passada na província, entre Minho e Douro. Tudo é caracteristicamente provinciano" (Correspondência 372). A ilustre casa de Ramires distinguishes itself from Eça's other texts in several ways. Written during a period of international humiliation for Portugal due to the 1890 British Ultimatum and internal turmoil brought on by the thwarted Republican Revolution that broke out in Porto in early 1891, the novel carries a deeply felt imprint of concerns over nationhood, political identity, abuse of power, and humiliation as the narrative explores Portugal's past through the mise en abyme of Gonçalo's historical diegetic novella. The function of this novella is complex: beyond a fictional revision of Portugal's history and a call for regeneration of Portuguese values and mores, the writing process itself and the novella's publication represent for Gonçalo the possibility of moving upward along the axis of power toward Lisbon, that is, from the província to the capital through political advancement.

It is worth noting that A ilustre casa de Ramires is one of three texts that Carlos Reis describes as "the definitive Eça," in that they represent the "culmination of a vast literary production that began in 1866" and are written during "the final, even conclusive, segment" of the author's life ("Last Novels" 85). From both a thematic and aesthetic point of view, A ilustre casa de Ramires represents the author's mature reflection on realism as a literary genre, and it is realism's openness and ambiguities (to which I will return) that matter most in Gonçalo's search for historical significance and public recognition.

To begin, Gonçalo is both physically and temporally removed from the center of power and social prestige - the former in relation to his political aspirations and the latter in comparison to the praiseworthy heroics of his ancestors. Given his peripheral status, Gonçalo's writing bears common ground with Hélène Cixous's disquisition on l'écriture féminine. First developed in her essay "The Laugh of the Medusa" (1976), Cixous coins the term to refer to non-representational and inherently playful writing that defies the maledominated center of power, reason, and language. Cixous refuses to bind this type of writing with a specific definition, and she instead uses metaphors such as milk, honey, and the ocean to describe what she perceives to be a disruptive, ludic, and deconstructive force capable of destabilizing, in Lacanian terms, the phallogocentric Symbolic Order. Perhaps most paradoxically, she also refuses to limit l'écriture feminine to women; rather, she argues that anyone can speak 
from the peripheral, marginalized footing of the feminine and so engage in this fundamental questioning of the masculine symbolic order. As Cixous sees it, l'écriture feminine can provide all language-using subjects with much-needed fluidity with respect to gendered, discursive, and sexual norms.

Transposed to the literary context of the nineteenth-century novel, l'écriture féminine provides a productive, analogous theoretical framework by which one might interpret the diegetic writing process that accompanies Gonçalo's developing masculinity. This reading details how with humor Eça pokes fun at the seriousness of historiographical writing and the text subtly frames forms of feminine writing, often a visceral, heartfelt experience-here also related to the musical genre of the Portuguese fado - at the margins of nineteenth-century society. This gendered development is a central narrative thread in A ilustre casa de Ramires, as Eça first presents Gonçalo as effeminate but then characterizes him, through an episode of physical conflict, as "soberbamente virilizado" (Ilustre casa 393). It is only after this transformation that Gonçalo finishes his novella. Indeed, during the first part of the novel, Gonçalo frequently struggles "to explode [the word], turn it around, and seize it" (Cixous, "Laugh" 887), to make it his own, given that he writes from a position of alterity, decentered and barred from political power, plagiarizing ideas and words to possess and produce language. After he adopts a more masculine demeanor, Gonçalo successfully completes and publishes the novella, illustrating how "writing has been run by a libidinal and culturalhence political, typically masculine-economy" (Cixous, "Laugh" 879), wherein men on the periphery (sexually, politically, socially, etc.) must also earn their right to write and wield the power that comes with it.

Gonçalo writes from a position of social dependence and political inferiority that denotes a marginalized writer who fears failure and rejection, a position that is far more arduous and decentered than might appear at first. While Gonçalo seems to possess all the privileges of a male, white fidalgo with a family inheritance that enables him to immortalize in prose the historical feats of his patrilineal ancestors, a closer examination of the text unveils how his 
coming to writing is surrounded by walls - political, gendered, class, societal, and sexual - that he must overcome to write. ${ }^{2}$

The parodic and humorous qualities of Eça's novel, which have certainly not gone unnoticed by critics, ${ }^{3}$ are likewise essential elements that blur narrative boundaries and subtly allow the text to incorporate fluidity, poke fun at and destabilize pre-established norms of gender, writing, and sexuality, such as the established early nineteenth-century genre of Romanticism's historic novel, heteronormativity, and images of dominant masculinity. Throughout the novel, Eça toys with a multiplicity of voices that provoke an intricately orchestrated and multilayered reaction to the above-mentioned rational prose centered on masculine phallic power, a reaction that is at the same time playful and humorous, consolidated through lineage and dominance of language in the public sphere, here explicitly connected to fin-de-siècle Lisbon and its print culture. This analysis works through the details of the diegetic writing processes to explore how the phallus in terms of political power is desired, challenged, displaced and undermined, and aims to show the vulnerability and inconclusiveness of Gonçalo's ultimate position after his coming into writing, as his departure from Portugal to Africa and subsequent narrative silence toward the end of the text make clear.

\section{Writing Oneself Out of the Margins}

A ilustre casa de Ramires depicts Gonçalo's writing process as he struggles to produce a four-chapter novella about his ancestors. The novella, pertinently titled, "A Torre de D. Ramires," mirrors the physical tower on the Ramires property, a "torre mais velha que o reino" according to the lyrics of a fado in the novel that likewise glorifies the Ramires family (Ilustre 118). Values pertaining to an ancient, traditional Portugal confront those of a constitutional,

\footnotetext{
${ }^{2}$ Here I am borrowing one of the key images from Cixous's essay on the difficulties that (female) writers face: "There are so many boundaries, and so many walls, and inside the walls, more walls" ("Coming to Writing" 3 ).

${ }^{3}$ See, for example, Remédios: "esse romance de Eça de Queirós constitui-se numa paródia, dizer que ele se constrói como paródia de um poemeto romântico; paródia do gênero romance histórico, paródia da própria História portuguesa. Nele também se destaca a ironia, marca indelével do autor, a qual exerce papel importante enquanto estratégia do discurso paródico" (797).
} 
parliamentary, and decadent fin-de-siècle nation as Eça weaves Gonçalo's social and political ambitions with his fascinating, fictional reconstruction of the history of his most heroic ancestor, albeit with an unfortunately sounding name: Tructesindo Ramires. Marie-Hélène Piwnik (45-46) and Daniel-Henri Pageaux (192-94) have carefully analyzed Gonçalo's “chic novella” (Ilustre 165 ) as a mise en abyme of the novel's storyline; furthermore, the symbolic importance of the historical novella, together with Gonçalo's insistence that it represents his ancestors, endows him with the prospect of social prestige and political success. As Gonçalo summarizes to his sister Graça and brother-in-law José Barrolo, his novella is "sobre um facto histórico da nossa gente [...]. Sobre um avô nosso, muito antigo, Tructesindo [... que fez] horrores. Mas é pitoresco [...], uma bela reconstrução do velho Portugal e sobretudo dos velhos Ramires" (Ilustre 164).

The age-old establishment of the Ramires family name, passed on for centuries and existing prior to the founding of Portugal, conveys a high stature to Gonçalo: predating the monarchy, he is, as one of his acquaintances realizes with enthusiasm, "mais fidalgo que o Rei!" (Ilustre 220). Laura Cavalcante Padilha develops this idea in her book-length study on desire in the novel. In relation to the tower on the Ramires property, Padilha discusses how its temporality, dating from the "moment zero" of the Portuguese and the Ramires family history, intertwines with Gonçalo's desire for this lost past: "Anterior à idade e guardadora da heroicidade, daí sua marca de anterioridade, marca que levará Gonçalo a tê-lo como objeto de seu desejo, pois que a vê como o símbolo da força, grandeza e poder que deseja para si” (Padilha 47). Riding on the prestige of his "imenso nome histórico" (Ilustre 98), Gonçalo, writing from Portugal's geographic and political margins, hopes to ensure his political career and literally free himself, through writing, from the "melancolias do seu buraco rural" (Ilustre 429). This correlates on several different levels with his aunt Louredo's dramatic plea, with almost a ring of eugenics to it, that her gallant and intelligent nephew should not bury himself in the província: "Lisboa está sem rapazes. Precisamos cá um bom Ramires!" (Ilustre 97). Later in the narrative, Gonçalo returns to this self-identifier when considering his position in relation to the heroics of his ancestors, and concludes, with satisfaction, that indeed "dentro do espírito e das expressões do seu século [ele] era pois um bom Ramires" (Ilustre 205). 
Gonçalo's identification with his ancestors intensifies through his writing, creating a symbiosis in the narrative that spans a variety of emotions from close cooption of his ancestors' honorable feats to shameful realization of his shortcomings. After Gonçalo writes pompously about Tructesindo's courageous resolve to honor his word avowed in a heroic declaration "de mal com o Reino e com o Rei, mas de bem com a honra e comigo!" (Ilustre 132), Gonçalo impersonates his honorable ancestor: with his vest unbuttoned he stands at the open window and, in a grave hoarse tone, gives out the "brado genial [...] como o lançaria Tructesindo" (Ilustre 132). Literally performing this expression of ultimate loyalty, the narrator emphasizes Gonçalo's proximity to his ancestors, "sentia nele realmente toda a alma dum Ramires, como eles eram no século XII, de sublime lealdade, mais presos à sua palavra que um santo ao seu voto, e alegremente desbaratando, para a manter, bens, contentamento e vida!" (Ilustre 132). Tructesindo's war cry and the honor to which it points stand in stark contrast to Gonçalo's immediate reality, namely, having broken a verbal agreement with one of his land tenants for his own material gain. Only much later in the narrative, when Gonçalo feels he has failed both politically and socially, he realizes his shortcomings in relation to his honorable ancestors: "Como a flor [de Portugal] murchara! [...] Todos eles, se História e Lenda não mentiam, de vidas tão triunfais e sonoras!" (Ilustre 379).

The longevity of the Ramires line is likewise represented in the objects that adorn the family home, from eighteenth-century tiles, Arras tapestries depicting the Argonaut's expedition, portraits of ancestors, porcelain from India and Japan kept in a large mahogany armoire, family silver, a diamond necklace and, intimately linked to Gonçalo's historical writing, the ancestral ink well that had served three generations of the Ramires family. Yet the details of the text reveal that the material presence of his ancestors appears in truth dilapidated and lacking prestige: the ancestral portraits are "denegridos e tristonhos" and so ugly that since his youth Gonçalo referred to them as "as caratonhas dos vovós" (Ilustre 119); the porcelain consists of unmatched pieces; the tapestries are faded; and the silver requires constant polishing. As Eça wrote in a succinct summary of the novel: "A casa do meu herói é um velho palacete, já empobrecido, e meio desmobilado" (Correspondência 372).

Despite Gonçalo's conscious efforts to immortalize his ancestral past, he ironically knows very little about the extent of his inheritance and his family 
property. This disconnect is vocalized when a neighboring fidalgo and politician Sancho Lucena indicates to him the far-off limits of the Ramires land, and Gonçalo reacts with surprise: "[É sítio] meu?" (Ilustre 155). Similarly, on a horse ride without any destination, Gonçalo comes across a bridge bearing his family's coat of arms that puzzles him and leaves him speculating as to their origin, proving once again to the reader the superficiality of his ancestral knowledge. The grandeur of the Ramires family lies in its past. In this provincial setting, the repetition of Gonçalo living at the dawn of time appears as a constant reminder that he and those around him have no descendants. The combination of Gonçalo without marriage prospects and his sister, Gracinha, uninterested in having children (while having an affair with her former suitor, Cavaleiro), points to the sterility of the Portuguese countryside and its lack of a legitimate future. As for the future, Gonçalo can only praise the fado composer and guitar player "Videirinha do violão" as "o derradeiro trovador português" (Ilustre 117), given that it is only through his verses, to which he continuously adds new elements, that the Fado dos Ramires lives on. This is a far less optimistic view than what one finds at the end of A cidade e as serras, a scene that revolves around Jacinto's children.

Against the physical heroics of the past, Gonçalo seeks glory through his writing. He perceives this to be equally noble and more fitting with the times: "um Ramires de nobres energias, não façanhudas, mas intelectuais, como competia numa idade de intelectual descanso" (Ilustre 205). His novella sets him apart in a period characterized by "a decadência dos fidalgos de Portugal" (Ilustre 205). As José Lúcio Castanheiro, Gonçalo’s former Coimbra companion and potential publisher emphatically states: "a literatura leva a tudo em Portugal! [...] De folhetim a folhetim se chega à cadeira de São Bento!" (Ilustre 84). When Gonçalo's anxiously awaited novella is a long time coming, Castanheiro inquires: "se essa Torre de D. Ramires se erguia enfim para honra das letras, como a outra, a genuína, se erguera outrora, em séculos mais ditosos, para orgulho das armas" (Ilustre 197). This explicit reference to the literal Ramires Tower of brick and mortar as "genuína” emphasizes how Gonçalo’s literary work borrows the name of the tower and draws from its historical stature: if the tower is the authentic and real entity, his novella is a substitute or imitation of an original erected during happier bygone years. 
Luce Irigaray has argued throughout her work on sexual difference that mimesis constitutes a playful strategy that enables a woman to "recover the place of her exploitation by discourse, without allowing herself to be simply reduced to it" (76). Gonçalo enacts an analogous form of mimicry, historically assigned to the feminine and aimed at subverting the patriarchal social order, when he aligns himself with playful insubordination, that is, when he "convert[s] a form of subordination into an affirmation, and thus [...] begin[s] to thwart it" (Irigaray 76). Gonçalo transfers the physical, virile heroics of his ancestors to the written page, justified by the conviction imparted to him by Castanheiro: "a pena agora, como a espada outrora, edifica reinos" (Ilustre 84), a revision of the Renaissance conceit articulated by Luís de Camões in Os Lusíadas, "numa mão a pena e noutra a lança" (131). Although mimesis in this case cannot be divested of its artistic, creative significance, Gonçalo's literary project appears from all perspectives to be an effeminate reenactment of past (masculine) courage and honor.

The belief that writing in newspapers "de folhetim a folhetim" leads to power is a constant theme in the novel. Just as Castanheiro hopes the prospects of a political position will lure Gonçalo to write, Gonçalo's former boss, Brás Vitorino, admonishes him: "Advogue, escreva nos jornais!" (Ilustre 98). Unable to become a lawyer given his "horror ingénito, quase psicológico, a autos e papelada forense" (Ilustre 98), Gonçalo's only option is to write for Castanheiro's newspaper, where he revelas an "imaginação e um saber rico" (Ilustre 98). His old acquaintance and would-be brother-in-law André Cavaleiro patronizingly encourages Gonçalo to write a "trabalho sério, de erudição forte, bem português" before entering into politics (Ilustre 156). ${ }^{4}$ The link between politics and writing is explicit, and it is clearly the desire for power that fuels Gonçalo's writing. Gonçalo's writing draws from his land-holding and noble family to raise his social status and serve his political ambitions. In Derridean

\footnotetext{
${ }^{4}$ Cavaleiro was a colleague of Gonçalo's in Coimbra, although he is several years older and already has an established career in politics before him. From the same region of Portugal as Gonçalo's family, he courted Gonçalo's sister Gracinha, but abandoned her abruptly. When Gonçalo becomes interested in politics, Cavaleiro promises to use his political influence to facilitate his appointment to office, and he seizes the opportunity to start up a new relationship with Gracinha, who is now married.
} 
terms, his writing "does not come to power. It is there beforehand, it partakes of and is made of it" (117).

Gonçalo's political advancement depends first on a venue to publish his novella, and the only option open to him is Castanheiro's Anais. It also requires the support of Cavaleiro, whose unethical abuse of power Gonçalo had publicly denounced when the former had abandoned the latter's sister. Cavaleiro, interested in the restoration of friendly relations between the two families given his renewed liaison with Gonçalo's married sister, repeatedly mentions his essential role in Gonçalo's political appointment: "E agora entras tu, pela porta que eu te abro!" (Ilustre 266). As Cixous argues, "the moment you receive something you are effectively 'open' to the other, and if you are a man you have only one wish, and that is hastily to return the gift, to break the circuit of an exchange that could have no end" ("Castration" 48). Gonçalo has nothing to offer Cavaleiro in exchange for political favors, that is, other than access to his sister, a relationship that is at first unknown to Gonçalo. This places Gonçalo in an inferior and vulnerable situation that Cavaleiro readily exploits, comparing Gonçalo's insecurities to a child anxious to receive dessert: "Sossega, menino, apanhas o teu arroz-doce!” (Ilustre 270). Toril Moi's commentary on Cixous's essay on castration is pertinent to Eça's text: "[the gift] seems to open up an imbalance of power. Thus the act of giving becomes a subtle means of aggression, of exposing the other to the threat of one's own superiority" (11011). Cavaleiro thus establishes the upper hand, with Gonçalo at his mercy and in his debt.

\section{Coming to Writing}

A large part of Eça's novel focuses on Gonçalo's writing process. Upon examining this process carefully, one finds Eça treating it with a great deal of irony; there is, for example, a stark contrast between the solemnity of what Gonçalo professes to be doing and the physical, intellectual, and emotional efforts of writing itself. As Reis indicates, Eça here "ends up casting upon the writing represented in fiction some of the ghosts that have persistently haunted his literary life: the crisis of originality, the obsessive stylistic elaboration, the trauma of plagiarism, etc." ("Last Novels" 90). From all aspects, Gonçalo is a lazy, ignorant writer, who has no scruples about plagiarism. In fact, with one of 
Eça's fabulous ironic touches, Gonçalo rejoices that he will not have to go to the trouble of consulting any archival material to write his novella: "Toda a reconstrução histórica a realizara, e solidamente, com um saber destro, o tio Duarte [num poema em verso solto]" (Ilustre 85). Gonçalo's plagiarized novella is a key element to understanding the overall meaning of the text: if the incredible feats of his ancestors were not cause enough to doubt the seriousness of the text, the fact that Eça's author-protagonist creates a farce of a historical novella proves that what we have is a simple fantasy of patrilineal heritage. The source of Gonçalo's writing is the voice of his ancestor Duarte, which he shamelessly appropriates. Gonçalo's act of blatant plagiarism does not seem to bother him; rather, it fuels his writerly ambitions and inspires him to produce other volumes and a few dull articles, including a treatise on "Visigoth Origins of Public Law in Portugal," though he knows next to nothing about either the origins of public law or the Visigoths. However, by plagiarizing a beautiful tome on the subject, he is confident that he can produce "corrediamente um resumo elegante" (Ilustre 99).

Beyond Duarte's poem on the Ramires family, Gonçalo also draws from Walter Scott, articles published in Panorama, and a volume of Alexandre Herculano's História to recreate a sense of the period. Even with these aids, however, he catches himself employing anachronistic elements, such as a book made of folio sheets of paper rather than a yellowed parchment. The Scott volume turns out to be more useful when thrown at the cook's cat about to pounce on a nest of blackbirds, and Gonçalo seems to see no value in an authentic letter that King D. Sebastião may have written to one of his ancestors in 1577, a year prior to the former's fatal expedition to Africa. Gonçalo can only read the date on the letter, so he deems it "perfeitamente inútil" except to serve as a wrapper for a flask of fruit salts (Ilustre 100).

Despite Gonçalo's political and literary ambitions, and his tendency to plagiarize, his coming to writing is not without continuous painstaking effort. Food that upsets his stomach (eggs, chorizo, cucumber), liver pains, the summer heat, insecurities about the upcoming election, exhaustion, and lack of inspiration are among the physical, mental, and emotional boundariesCixous's walls within walls - that he has to overcome. The absence of his closest friends amplifies his feeling of discouragement. Even when flagrantly plagiarizing Duarte's dense poem, the project seems endless and unmanageable 
to him:"desenrolada como um novelo solto-sem que ele lhe pudesse encurtar os fios, tão cerradamente os emaranhara no seu denso poema o tio Duarte, que ele seguia gemendo!" (Ilustre 363). Moreover, Gonçalo takes issue with Duarte's interpretation of certain episodes (i.e., the friar in disguise stealing a kiss from the maiden at the well; Tructesindo overcome with grief for his murdered son), and he concludes that Duarte "não sentia hereditariamente a fortaleza da raça —e, romântica plangente de 1848, inundara logo de prantos românticos a face férrea de um lidador do século XII, dum companheiro de Sancho I!" (Ilustre 242). Gonçalo thus sees it as his mission to reestablish the true spirit of the epic: he crosses out the section copied from Duarte and starts over. In Gonçalo's view, since Duarte was not a Ramires, he could not be sufficiently in tune with the history of the Ramires dynasty. As a direct descendant, Gonçalo decides to write through his lineage in order to reestablish his honor and that of his raça. ${ }^{5}$ This concept of raça has several meanings within the text, and at times these meanings are combined. On occasion, it refers to the Ramires lineage, so ancient that it could be referred to as its own race. At the end of the narrative, however, a relative characterizes Gonçalo by exclaiming: "Tem muita raça! [...] E é o que o salva dos defeitos. [...] Muito leviano, muito incoerente. [...] Mas tem a raça que o salva" (Ilustre 455). Ofélia Paiva Monteiro provides a pertinent, detailed analysis of this concept of race that she reads as equivalent to "elegância de porte, gosto, bom coração, simplicidade, afabilidade com iguais ou com humildes, capacidade judicativa dos outros e de si mesmo, graça, verve (e por vezes bem cáustia) qualidades que o distinguem da gente impante mas grosseira" (24). By revisiting the grandeurs of the past through writing, Gonçalo emerges with the strength of his ancestors, resurrecting both aspects of his raça.

Gonçalo's true writing breakthrough happens after he experiences a surge of courage in an attack that brings him to be recognized as "um verdadeiro Ramires, dos antigos na História. [...] Enfim era um homem!” (Ilustre 393-94).

\footnotetext{
${ }^{5}$ The process of writing through one's lineage could be considered homologous to Cixous's call for women to "write through the body": "By writing her self, woman will return to the body. [...] Write your self. Your body must be heard" ("Laugh" 880). Just as women recuperate their bodies through writing, here Gonçalo, as a representative of a waning generation of fidalgos, revives the memory of his ancestors through the writing of his family history.
} 
Armed with an ancient whip that Bento had come across in the attic and that his relative Titó predicts could kill a man, Gonçalo engages in a bloody attack on Ernesto de Nacejas, a haughty youth with blond sideburns whom Gonçalo had perceived as a threat on more than one occasion. Leaving the Nacejas boy and his companion for dead, the news quickly became widespread in both local and national newspapers, news that Gonçalo devours: "Todos contavam, todos celebravam!" (Ilustre 416). Gonçalo is welcomed at the local Assembly like the victor of an illustrious battle, and telegrams pour in from around the country to congratulate him on his courageous victory, leaving Gonçalo feeling empowered: "todas as dificuldades da vida lhe apareciam agora, de repente, naquele frescor da sua coragem nova, tão fáceis de abater como os desafios dos valentões" (Ilustre 399). As he gazes out toward his ancestral tower, always the symbol of his honorable ancestors and the grand past of Portugal, Gonçalo feels a greater, more intimate harmony, "como se a sua força, tanto tempo quebrada, se soldasse enfim firmamente à força secular da sua raça" (Ilustre 403).

Most importantly, Gonçalo's newfound courage and feeling of invincibility overflows into his writing, which he reinitiates with ease as he attacks "o lance de tanto sabor medieval" to depict the scene of Tructesindo and his men on the tail of their enemy, the Bastardo (Ilustre 410). Beyond the ease with which Gonçalo renders this adventure scene, his written words in the margins of the paper create a palimpsest effect: with the date he indicates his "briga terrível" with two men whom he castigated severely; at the end of the evening, and at the end of chapter four, he writes another note in the margin: "Meia-noite [...] Dia cheio. Batalhei, trabalhei" (Ilustre 412). The Nacejas attack reinforces the synergic quality of Gonçalo's writing, bringing the heroics of the past from this very same region to life. Symbolically, with his new masculinity, Gonçalo no longer walks between walls, and the meanings flow.

In contrast to Gonçalo's rise to courage and virility (and his subsequent political success), there is an episode in the novel that appears to conflict with his project, namely, the appointment of an effeminate colleague to public office. Emblematically, it is through the remarks of João Gouveia, considered the most politically impartial character of the novel, that Eça includes commentary on the male-dominated, heteronormative politics of his day. In a short but significant passage, Eça focuses on the nomination of one of the group's former Coimbra colleagues, António Moreno (whom the group used to 
call "Antoninha Morena"), to the position of Civil Governor. Gonçalo and his friends view this nomination as "a derradeira degradação" given António's propensity to cross-dress. All they need now, Gonçalo states with dissatisfaction and irony, is to appoint a woman, a Joana Salgadeira, to the office of the crown's General Procurer for there to be a perfect harmony of all government services (Ilustre 102). This short episode, through the reaction and discussion of the Coimbra group, reiterates the strong masculinist tendencies of Portuguese politics. Paradoxically, António Moreno achieves political advancement prior to Gonçalo, a fact that calls into question the link the protagonists establish between heteronormativity, masculinity, public office and power.

\section{Beyond "Masculine" Prose}

Apart from the dramatization of Gonçalo's writing process, Eça also sprinkles A ilustre casa de Ramires with multiple forms of writing and creation. Each of these resonates at some level with or in opposition to Gonçalo's writing process, its outcome, and the social status of an ultimately "soberbamente virilizado" political candidate and fidalgo.

The Fado dos Ramires, performed at key moments of the novel, remains a symbolic reminder of the greatness of times past. The fundamental concept that the fado embraces is the glory of the "Velha casa de Ramires, / Honra e flor de Portugal!" (Ilustre 259). Videirinha is considered a reputable musician of the municipal capital Vila Clara, the son of the village baker, a pharmacy assistant by profession, and a poet of love and patriotic verses, with the seal of approval of his published poems in a local newspaper, the Independente de Oliveira. He is one of Eça's many secondary characters that embody marginalized positions in relation to the plot and the norms of society. Effeminate and solitary, "Videirinha do violão" appears at random, wandering the night along country roads with his guitar, playing his Fado dos Ramires to himself and the moon, in the "dolente melodia" of the Coimbra mode, plentiful in sighs (Ilustre 117). Outside the Assembly, he waits for Gonçalo, almost stalking him: "não pertencia à Assembleia, mas rondava, esperando o Fidalgo para lhe lançar duas trovas do Fado, improvisadas nessa tarde, em que o exaltava acima dos outros Ramires, da História e da Lenda!” (Ilustre 414). Forever grateful to Gonçalo for 
publically acknowledging him with a handshake - "uma glória, quase uma coroação, e sempre nova, sempre deliciosa" (Ilustre 117) — he expresses his gratitude by immortalizing him with the lyrics of the Fado dos Ramires, aided by the expertise of father Soeiro, chapelain and archivist of the Ramires Tower.

The Fado dos Ramires moves intermittently from a background presence to the foreground, where it accompanies the narrative thread of the plot. When a social scandal orchestrated by Cavaleiro erupts that outrages Gonçalo, he encloses himself in his room while his brother-in-law hums the tune of the fado, and in the living room his sister hammers it out on the piano (Ilustre 190). At Gonçalo's mention of Cavaleiro's abuse of power when his love interests were rejected, Gracinha's playing quietens down, and her performance of the fado "esmorec[e], apenas roçado, num murmúrio incerto" (Ilustre 191). When Gonçalo comments that Cavaleiro is "namoradíssimo, todo em chamas pela irmã mais velha do Noronha," the fado breaks up altogether "num tumulto de gemidos desconcertados e ásperos" (Ilustre 191) and Gracinha freezes at the piano. Symbolically, the silencing of the fado portends Gracinha's ongoing feelings for André and their future affair, which will be the cause of the most pain and humiliation for Gonçalo.

Through Videirinha's Fado dos Ramires, Gonçalo enters history and, alongside his valiant ancestors, becomes immortalized in verse. Gonçalo reiterates the seriousness of Videirinha's fado when his cousin D. Maria Mendonça accuses the former of knowing little of the Ramires family history beyond the song: "O fado do Videirinha está fundado em documentos autênticos que o padre Soeiro estudou. Todo o recheio histórico foi fornecido pelo padre Soeiro. O Videirinha só pôs as rimas. Além disso antigamente, prima, a história era perpetuada em verso e cantada ao som da lira" (Ilustre 316). Here Gonçalo emphasizes the link between Videirinha's performance of the fado and the Portuguese tradition of sung poetry (as far back as the medieval cantigas of Provençal influence), adding a degree of solemnity to Videirinha's composition. However, in typical Eça fashion, even the apparently serious writing process of the historically based fado endowed with the church's seal of approval is peppered with humor. Videirinha uses poetic license, for example, in the stanza about Santa Aldonça: the saint is said to have been carried on the shoulders of four kings and numerous counts, but Videirinha couldn't fit the counts because of the rhyme. 
Beyond Gonçalo's novella and the mention of Father Soeiro entertaining himself writing a book on the history of the bishops of the Cathedral of Oliveira, only in personal letters does the narrative voice become feminized. Among these are the letters written by the gossipy, conniving Lousadas sisters, whom the narrator colorfully describes as "secas, escuras e gárrulas como cigarras" (Ilustre 182). Unlike Gonçalo, who can write an opinion to the newspaper, the Lousadas resort to anonymous letters, such as the particularly malicious one they send to José Barrolo to denounce Cavaleiro's affair with Gracinha.

When Gonçalo departs for Africa, the significance and prestige of the Ramires family ancestry recedes from view. Gracinha's letters to Gonçalo summarize their existence as a "ramerrão costumado," and the narrator emphasizes this condition: "E com efeito a vida recomeçara, no seu ramerrão, simples, contínua, e sem história, como corre um rio claro numa solidão" (Ilustre 447). Fitting with the norms of the nineteenth century, Gracinha's existence represents her exclusion from the realm of writing and illustrates Cixous's lamentation to women that "you can desire. You can read, adore, be invaded. But writing is not granted to you. Writing is reserved for the chosen" ("Laugh" 13). Without Gonçalo, there is no history and no writing. Symbolically, this lack of the written word (and the history it immortalizes) is evoked when Videirinha pokes his head around the door of Gonçalo's library in his absence and sees "o molho de penas de pato espetado no velho tinteiro de latão, que esperava, rebrilhando solitariamente sobre a mesa nua sem papéis nem livros" (Ilustre 452). Deprived of the opportunity afforded by serious writing, Gracinha's only opportunity to represent the Ramires clan is through her needlework. In the tower, she goes to the room of her youth to relive her unmarried days, surrounded by antique objects such as a dressing-table that had once belonged to the Queen Dona Maria Francisca of Savoy and a beautiful inlaid wooden bed. There she embroiders the black Ramires goshawk, an ongoing endeavor of many years. Gracinha is like the other women in the novel: their voices are muffled, and they have "no legitimate place, no land, no fatherland, no history of [their] own" (Cixous, "Coming to Writing" 15). Furthermore, as Regina Michelli Ferretti finds in the novel, women are consistently defined by their silence and absence in both the main storyline and the novella: "A mulher constitui-se ainda como ausência [...]. A heroicidade se 
inscreve no território masculino, uma vez que nenhuma mulher assume a primazia na ação, funcionando apenas como o fundo em que brilha a figura do homem" (687). Symbolic of this clear gender divide is cousin D. Maria Mendonça's obsession with visiting the ruins of the Ramires family and by extension those of Portugal: its past grandeurs, ancestral tombs, rural chapels, and crypts. Devoured by her preoccupation with noble lineages, D. Maria Mendonça earnestly attempts to link her ancestry to that of the noblest houses of Portugal, "sobretudo, mais gulosamente, à grande Casa de Ramires" (Ilustre 169). Through Eça's touch of irony, these colorful episodes, which may appear anecdotal, are in fact a nod in Herculano's direction and a comic reenactment of Romanticism's greatest gothic tropes.

D. Maria Mendonça's letter-writing abounds with stereotypical female characteristics. They are incoherent, elliptical, and trivial. The letter she writes to Gracinha, which is the only description in the text of Gonçalo's triumphant return from Africa, is full of irrelevancies that diminish the importance of his return, relegating it to a secondary plane in comparison to the frivolities that dominate her existence, such as the color of her dress, hat, and ribbons, and the heat of Lisbon. The information D. Maria Mendonça does include in her letter about Gonçalo speaks of his success in Africa, where he planted two thousand coconut trees and cultivated a lot of cocoa and rubber. Most importantly, D. Maria Mendonça describes how he returns with notes for a new book project and appears manlier: "Não imaginas como vem [...] óptimo! Até mais bonito, e sobretudo mais homem" (Ilustre 450).

If Gonçalo had to leave for Africa to become "mais homem," then writing his historical, masculine novella was not enough. At several moments in the narrative, Gonçalo shows great satisfaction toward his own writing: in a moment of sudden inspiration, he exclaims, "Caramba! Aqui há talento!" (Ilustre 131); when he writes the open letter to the local newspaper to condemn Cavaleiro, he states that he has done his duty of a good citizen and with style ("cumpri esse bom dever. E com certo brilho, louvado Deus!" [Ilustre 192]); on another occasion, after finishing a chapter that he had been toiling over for a week, he reads his work and concludes "que o lance impressionaria" (Ilustre 340); he is eager to show his work to his sister and Father Soeiro to receive, without further delay "os louvores merecidos" (Ilustre 340). When Gonçalo sends his first chapters to Castanheiro, the telegram he receives in return is 
filled with enthusiasm: "Capítulos romance recibidos. Leitura feita amigos. Entusiasmo! Verdadeira obra-prima! Abraço! (Ilustre 409). For Castanheiro, Gonçalo's writing is preferable to Gustave Flaubert's Salammbô and his epic realism has a stronger historical reconstruction than Herculano or Luís Augusto Rebelo da Silva. However, when Gonçalo finally finishes his novella, he does not feel the degree of happiness he expected, and he even doubts the final gruesome scene in his source where leeches suck the Bastardo's blood a drop at a time. He is left with a feeling of aversion for that distant world, "tão bestial, tão desumano!" (Ilustre 429). Only the thought of public praise, his family fame spread widely, and the prospects of the election give him a glimpse of optimism: “O seu Verão, pois, fora fecundo" (Ilustre 429).

If Gonçalo's writing, ancestral courage, and political career bring him to the height of his social acceptance, how can we interpret his sudden departure to Africa? The end of the novel is inconclusive. There are no indications as to Gonçalo's future. He is absent. For Carlos Reis, Eça chooses at the end of the novel "to convey indefinite and relative meanings, delivered by a narrator who has waived his right (or failed) to draw a conclusion. It is as if Realism, although still possible at a technical level, had ceased (literally) to make sense, in the light of a new aesthetics that is also a new ethics for the artistic process" ("Last Novels" 91). There is indeed a plurality of voices at the end of the narrative, and most unusually, the dominant voice is feminine: D. Maria Mendonça's letter relating Gonçalo's return.

Since its publication, A ilustre casa de Ramires has often been considered a patriotic text, or even a manifesto, projecting the past glories of Portugal onto the matrix of fin-de siècle decadence and humiliation. The text brings to the forefront the relation between the intellectual and the historical past, or rather the dialect between tradition and renovation, that was vividly present in Portugal since the consolidation and theoretical affirmation of ideas stemming from the so-called Generation of 1870. In the text, Gonçalo's decision to leave for Africa refers to the extra-textual context of Portuguese history, namely, the need to overcome the weaknesses that affect the nation by regenerating the country's colonial resources. Yet, the end of the text is open-ended. After the narrative has focused throughout on Gonçalo's writing process, how can we interpret his absence, narrative silence, and the inherent ambiguities that constitute the final pages of the novel? The reader might expect Gonçalo's 
painstaking writing exercise to reinforce a reconstruction of fin-de-siècle provincial Portugal that in some degree either echoes or critiques a phallogocentric nation based on a patrilineal ancestry.

In the end, however, there is no closure. D. Maria Mendonça gives the final send-off to summarize Gonçalo's African sojourn, a vague mention of his economic prospects, and eventually a new book project, but the letter is not read in its entirety. It is as though D. Maria Mendonça's letter and the dispersed conversation among Gonçalo's acquaintances steer clear of any definitive meaning. Even when João Gouveia proposes the resemblance between Gonçalo and Portugal, "assim todo completo, com o bem, e com o mal" (Ilustre 456), as the opinion of a single narrative voice it appears inconclusive. Has he indeed risen to the masculine through his writing and his return from Africa? The novel's ambiguous ending leaves the success of Gonçalo's writing in suspension and his future unclear. Yet one fact remains evident: through Gonçalo's coming to writing, his efforts toward inscribing masculinity, his political career and African experiment, he successfully escapes the província, proving once again that "Lisboa é Portugal [...]. Fora de Lisboa não há nada $[\ldots] . "$

\section{Works Cited}

Camões, Luís de. Os Lusíadas. Gonçalvez, 1572.

Cixous, Hélène. "Castration or Decapitation?" translated by Annett Kuhn, Signs, vol. 7, no. 1, 1981, pp. 41-55.

- . "Coming to Writing” and Other Essays, edited by Debora Jenson, translated by Sarah Cornell, et al., Harvard UP, 1991.

- . "Laugh of the Medusa," translated by Keith Cohen and Paula Cohen, Signs, vol. 1, no. 4, 1976, pp. 875-93.

Derrida, Jacques. "Scribble (Writing-Power)." Yale French Studies, no. 58, (1979), pp. 117-47.

Ferretti, Regina Michelli. "Eça de Queirós e a ilustre casa do universo feminino." 150 anos com Eça de Queirós: III Encontro Internacional de Queirosianos, U de São Paulo, 1997, pp. 685-91.

Irigaray, Luce. This Sex Which is Not One, translated by Catherine Porter, Cornell UP, 1985. 
Lacan, Jacques. Feminine Sexuality. Jacques Lacan and the école freudienne, edited by Juliet Mitchell and Jacqueline Rose, translated by Jacqueline Rose, Pantheon, 1985.

Moi, Toril. Sexual/Textual Politics. Feminist Literary Theory. Routledge, 2002.

Monteiro, Ofélia Paiva. "A figuração 'problematizadora' de Gonçalo Ramires." Revista de Estudos Literários, vol. 4, 2014, pp. 15-42.

Padilha, Laura Cavalcante. O espaço do desejo: uma leitura de A ilustre casa de Ramires de Eça de Queirós. U de Brasília, 1989.

Pageaux, Daniel-Henri. "A ilustre casa de Ramires: da 'mise en abyme' à busca do sentido." Actas do colóquio Eça e Os Maias cem anos depois, Asa, 1990, pp. 191-96.

Piwnik, Marie-Hélène. Eça de Queiroz revisitado (propostas de leitura), translated by A. Campos Matos, Opera Omnia, 2012.

Queirós, Eça de. A capital! (começos duma carreira), 1925, edited by Luiz Fagundes Duarte, Imprensa Nacional-Casa da Moeda, 1992.

- A cidade e as serras. Lello \& Irmão, 1901.

-. A correspondência de Fradique Mendes. Chardron, 1900.

-. A ilustre casa de Ramires, 1900, edited by Elena Losada Soler, Imprensa Nacional-Casa da Moeda, 1999.

- Correspondência, 1928, 2 vols, edited by Alfredo Campos Matos, Caminho, 2008.

-. Os Maias: episódios da vida romântica, edited by Carlos Reis and Maria do Rosário Cunha, Imprensa Nacional-Casa da Moeda, 2018.

Reis, Carlos. O essencial sobre Eça de Queirós. Imprensa Nacional-Casa da Moeda, 2000.

—. "The Last Novels of Eça de Queirós: Realism as a Problem." Portuguese Studies, vol. 14, 1998, pp. 84-91.

Remédios, Maria Luíza Ritzel. "A ilustre casa de Ramires: história e paródia." Congresso de Estudos Queirosianos. IV Encontro Internacional de Queirosianos, vol. 2, Almedina, 2002, pp. 788-99. 